\title{
PERBEDAAN ORIENTASI TATA LETAK SANGGAH DI BANJAR BEDUGUL, DESA PENATAHAN
}

\author{
Oleh: \\ I Putu Udiyana Wasista \\ udiyanawasista@isi-dps.ac.id \\ Jurusan Desain Interior Fakultas Seni Rupa dan Desain \\ Institut Seni Indonesia Denpasar
}

Proses Review 19-26 April, Dinyatakan Lolos 28 April

\begin{abstract}
This study puts forward the layout pattern of the sanggah in Banjar Bedugul. This phenomenon is caused by the different overall layout of sanggah. If the layout of the sanggah is roughly in the kajakangin direction, something different has happened to Banjar Bedugul. This study used a qualitative method with an emic approach presented descriptively. In this paper, there is no specific theory that attempts to collide with phenomena. This is because this study is the beginning of similar research. The emic approach was chosen because the people's perspective is a valuable material for consideration in subsequent research. As for the literature used, it aims to explain rather than dissect the phenomenon. As a result, the sanggah layout in Banjar Bedugul is located in front of the entrance to the courtyard. This situation is caused by the residents' representatives placing their objections upstream on the public roads. Upstream refers to the road and direction of kaja, to the direction of Pura Batur Jati. Judging from the source of Banjar Bedugul's public road, this led to sanggah directed in the direction of kaja-kangin and kaja-kauh. The value obtained from interviews and observations is based on religious mystical thinking, the value of collective, preservation, and identification.
\end{abstract}

Keywords: sanggah, architecture, traditional, Bali

\begin{abstract}
Abstrak
Penelitian ini mengangkat pola tata letak sanggah di Banjar Bedugul. Fenomena ini diangkat karena adanya perbedaan dengan pola tata letak sanggah pada umumnya. Apabila tata letak sanggah pada umumnya di arah kaja-kangin, hal berbeda terjadi di Banjar Bedugul. Penelitian ini menggunakan metode kualitatif dengan pendekatan emik yang disajikan deskriptif. Dalam tulisan ini, tidak ada teori khusus yang berusaha untuk dibenturkan dengan fenomena. Ini karena penelitian ini adalah awal dari penelitian sejenis. Pendekatan emik dipilih karena cara pandang warga adalah material berharga untuk pertimbangan penelitian berikutnya. Adapun literatur yang digunakan,
\end{abstract}


lebih bertujuan untuk menjelaskan bukan membedah fenomena. Hasilnya, tata letak sanggah di Banjar Bedugul berada di depan pintu masuk pekarangan. Kondisi ini muncul dari representasi warga untuk meletakkan sanggah dengan hulu ke jalan umum. Hulu mengacu pada jalan dan arah kaja yaitu Pura Batur Jati. Ini menyebabkan sanggah berada di arah kaja-kangin dan kaja-kauh, bila dilihat dari hulu kaja-kelod jalan umum di Banjar Bedugul. Nilai-nilai yang didapat dari wawancara dan observasi adalah nilai yang didasarkan pada pemikiran mistis religius, kolektif, pelestarian dan identitas.

Kata Kunci: sanggah, arsitektur, tradisional, Bali

\section{PENDAHULUAN}

Sanggah erat kaitannya dengan kehidupan religius masyarakat Bali. Sanggah adalah sebuah tempat suci bagi keluarga di suatu pekarangan. Tempat suci ini disebut juga dengan nama mrajan, sanggah merajan, penghulun karang, sanggar kamimitan, sanggah kemulan, atau sanggah pemerajan (Suardana dkk., 2018; Sudana dkk., 2020; Wikarman, 1998; Winanti, 2009). Namun di daerah penelitian, tempat pemujaan ini cukup disebut dengan sanggah.

Pembangunan sanggah mengikuti aturanaturan dalam arsitektur tradisional Bali. Salah satu aturannya adalah mengatur arah orientasi dan tata letaknya di pekarangan. Aturan ini erat kaitannya dengan arah kaja-kelod dan kanginkauh dalam kosmologi Hindu Bali. Biasanya, di pekarangan rumah tinggal, sanggah diletakkan di arah kaja-kangin (Dwijendra, 2003). Arah ini adalah ruang paling sakral dalam konsep pembagian zona yang disebut sanga mandala. Konsep sanga mandala terbentuk dari persilangan arah kaja-kelod (gunung-laut) dan kangin-kauh (terbit terbenam matahari) (Suryada, 2012). Nilai arah kaja-kangin dalam konsep sanga madala adalah utamaning utama. Oleh karena itu, arah ini dinilai sangat ideal digunakan sebagai areal tempat suci.

Namun, tata letak sanggah di Banjar Bedugul, Desa Penatahan tergolong unik. Dari segi arah orientasi dan tata letak berbeda dengan konsep sanga mandala di atas. Tata letak sanggah-nya tidak menggunakan pola kaja-kangin pada umumnya, melainkan diletakkan di depan pintu masuk pekarangan. Ini menyebabkan ada sanggah yang terletak di arah kaja-kangin dan kaja-kauh jika dilihat dari posisi kaja-kelod jalan umum banjar.

Pola tata letak sanggah ini diikuti oleh seluruh warga Banjar Bedugul tanpa terkecuali, baik pendatang maupun yang sudah lama menetap di sana. Selain itu, orientasi arah sumbu kajakelod di Banjar Bedugul, berbeda dengan desa induknya yaitu Desa Penatahan. Sumbu kaja Desa Penatahan mengarah ke Gunung Batu Kau. Sedangkan warga Banjar Bedugul menggunakan sumbu kaja miring ke timur laut dari posisi Gunung Batu Kau.

Konsep desa, kala, patra menciptakan suatu sistem kolektif di masyarakat. Apalagi dengan kondisi kehidupan yang komunal, menyebabkan sistem kolektif ini masih bertahan di Bali. Sistem ini melibatkan gejala tertentu yang muncul di masyarakat. Hal yang berlaku sama dengan fenomena tata letak sanggah di atas. Melalui artikel ini, tata letak sanggah akan dibahas dari perspektif nilai-nilai yang mendasarinya. Tujuannya untuk mengetahui pola pikir masyarakat Banjar Bedugul secara pragmatis dan filosofis terhadap tata letak sanggah-nya.

Selain itu, masih sedikit literatur yang menjelaskan konsep tata letak sanggah selain di orientasi kaja-kangin. Studi literatur terhadap orientasi tata letak sanggah/merajan telah dilakukan sebelumnya. Literatur yang dicari adalah literatur yang berisi orientasi tata letak sanggah/merajan. Dari literatur yang ditulis oleh Dwijendra (2003; 2010); Gelebet (1986); Suardana dkk. (2018); Suarya (2003); Sudana dkk. (2020); Widiyani dan Wiriantari (2019); Wikarman dan Singgih (1993); Wikarman (1998); Winanti (2009), semuanya menjelaskan arah kaja-kangin sebagai orientasi dan zona sakral untuk menempatkan sanggah.

Literatur berbeda tentang orientasi tata letak 
sanggah, ditemukan pada tulisan milik Yulianasari dkk. (2020). Tulisan ini membahas orientasi dalam tata letak sanggah di Desa Bayung Gede. Perbedaannya dengan literatur yang lain adalah tata letak sanggah-nya yang hanya mengacu pada hulu kaja-kelod. Jadi, sanggah di Desa Bayung Gede ditempatkan pada arah kaja. Posisinya terhadap pekarangan bervariasi, bisa diapit rumah tinggal (berada di tengah pekarangan) ataupun tidak. Uniknya, terdapat perbedaan menarik antara tata letak sanggah di Bayung Gede dan di Banjar Bedugul. Jika tata letak sanggah di Bayung Gede menjauhi jalan (rurung), tata letak sanggah di Banjar Bedugul malah sebaliknya.

Dari penjelasan di atas, masih sedikit literatur tentang orientasi tata letak sanggah selain arah kaja-kangin. Oleh karena itu, sangat menarik untuk mengkaji keunikan posisi peletakan sanggah di Banjar Bedugul, yang berbeda dengan pola pembagian sanga mandala di arah kaja-kangin. Melalui artikel ini, semoga dapat memberikan referensi lain tentang konsep tata letak sanggah dalam seni arsitektur tradisional Bali.

\section{METODE PENELITIAN}

Penelitian ini menggunakan metode pengumpulan data kualitatif melalui pendekatan emik yang disajikan deskriptif. Pendekatan emik adalah proses untuk mengkaji temuan tanpa digeneralisasikan dengan subyek/obyek lain di tempat yang lain. Ini artinya representasi sudut pandang lebih dari sudut pandang dari dalam subyek (Gumilang, 2016).

Pendekatan emik dipilih karena beberapa pertimbangan Pertama, kajian kasus serupa dan data literatur belum ditemukan, sehingga penelitian ini adalah awal dari penelitian sejenis. Pernyataan warga dianggap sebagai material yang sangat berharga. Kedua, pendekatan ini dilakukan untuk menemukan kesimpulan dari pernyataan warga tanpa menguji dengan teori apapun. Ini dilakukan karena warga memiliki cara pandang sendiri yang justru menjadi kekayaan intelektual tersendiri dalam arsitektur tradisional Bali. Daripada menguji dengan teori, lebih baik menerima dan merumuskan pernyataan tersebut sebagai pijakan penelitian selanjutnya. Perbedaan cara pandang ini justru akan semakin menguatkan nilai seni tradisi khususnya seni arsitektur tradisional.

Data yang dikumpulkan bersifat primer dan sekunder. Data primer didapat melalui wawancara dan observasi langsung. Data sekunder didapat melalui penelusuran literatur. Setelah data terkumpul, digunakan model Miles dan Huberman untuk menganalisisnya (Sugiyono, 2010). Proses analisis data model Miles dan Huberman, meliputi : 1) Reduksi data; 2) Penyajian data; 3) Kesimpulan. Kemudian dari seluruh data yang terkumpul, direduksi menjadi bentuk dan nilai-nilai dalam tata letak sanggah. Kemudian data diinterpretasi dan dibahas untuk ditarik sebuah kesimpulan.

\section{ANALISIS DAN INTERPRETASI DATA}

\section{Pengertian Sanggah dan Tata Letaknya di Pekarangan Rumah Tinggal}

Istilah sanggah berasal dari Bahasa Kawi yaitu sanggar, sebagai tempat untuk pemujaan suci (Winanti, 2009: 18). Dalam sumber lain, sanggah berasal dari kata sanggar yang artinya kuil. Lebih lanjut, sanggah dapat juga mengacu pada kata sangga dalam kaitannya dengan kata anangga. Dalam hal ini, anangga berarti memegang tinggi-tinggi, yang dapat dikaitkan dengan makna menjunjung atau memuja (Soebandi, 2008: 24).

Dari literatur di atas, pemujaan ditujukan kepada arwah leluhur yang berada di sanggah. Orang Bali percaya apabila arwah orang mati yang telah disucikan, akan ditempatkan di sanggah. Arwah ini kemudian dipercaya akan menjaga sanak keturunannya dan memberi berkat. Dalam konteks genealogi masyarakat Bali, sanggah diperuntukkan sebagai pemujaan untuk satu garis keturunan keluarga. Jadi dalam hal ini, pengertian sanggah mengacu pada sebuah tempat pemujaan leluhur dalam suatu keluarga. Biasanya sanggah diletakkan dalam sebuah pekarangan, serta dibatasi pagar sebagai pembeda zona dengan rumah tinggal.

Tata letak sanggah mengacu pada orientasi arah religi gunung-segara (kaja-kelod) dan terbit terbenam matahari (kangin-kauh). Selain itu, tata letak sanggah mengacu pada hierarki konsep beten beduwur/luan teben (Winanti, 


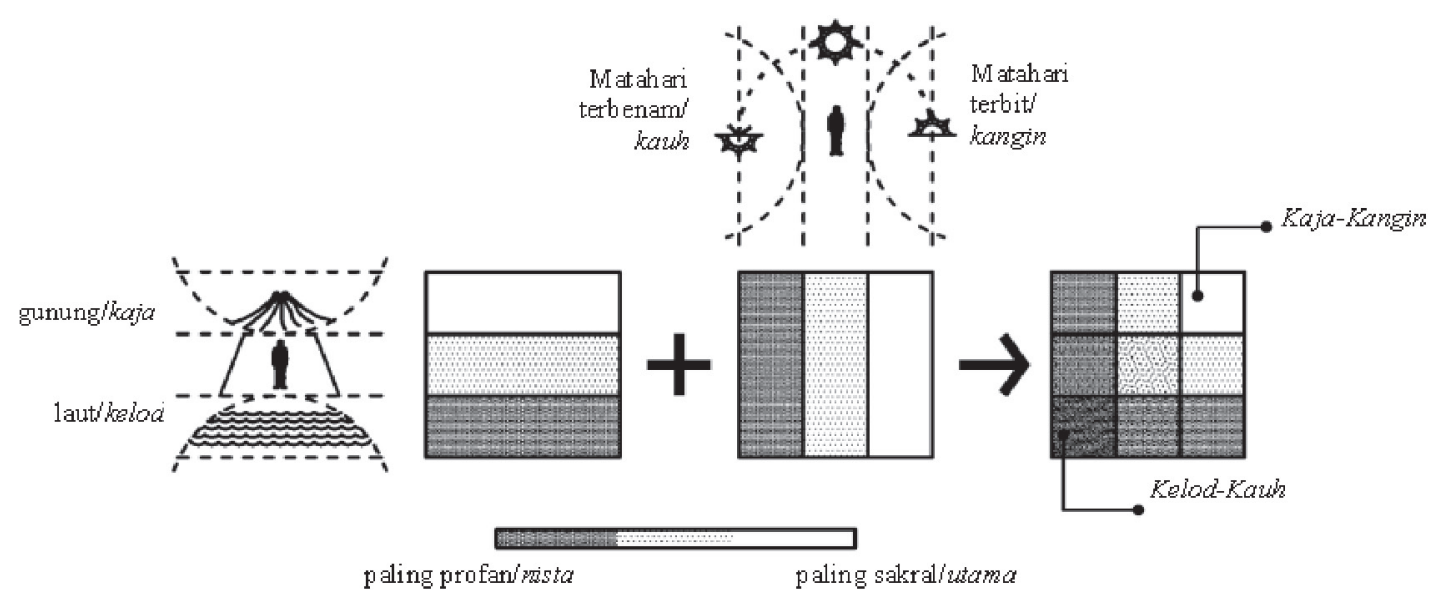

Gambar 1. Persilangan Kaja-Kelod dan Kangin-Kauh

(Sumber : Suryada, 2012)

2009: 48). Dari penjelesan itu, orientasi tertinggi (beduwur/luan) mengacu pada gunung (kaja) dan terbit matahari (kangin). Persilangan kedua orientasi tersebut adalah arah kaja-kangin. Kaja dan kangin adalah hulu dalam perspektif orientasi masyarakat Bali. Keduanya bernilai utama atau memiliki nilai yang dianggap sakral. Dengan demikian, persilangan keduanya yakni arah kaja-kangin, dianggap memiliki nilai paling utama atau sakral.

Di sisi lain, dalam pembagian zona sanga mandala, arah kaja-kangin memiliki nilai utamaning utama (Dwijendra, 2010). Area dengan nilai ini adalah area dengan nilai paling sakral, sehingga sangat ideal sebagai area tempat suci. Berikut ini gambar terbentuknya orientasi ruang sakral dan profan di Bali.

Seperti terlihat pada gambar 1 . di atas, dari persilangan orientasi kaja-kelod dan kanginkauh terbagi menjadi sembilan zona yang disebut sanga mandala. Di pembagian zona ini, arah kaja-kangin adalah ruang bernilai paling sakral (utama). Sedangkan arah kelod-kauh bernilai paling profan (nista). Aturan penentuan orientasi utama-nista ini dilakukan oleh masyarakat Bali. Apabila ingin membangun rumah tinggal, penentuan orientasi utama-nista mutlak dilakukan terlebih dahulu. Setelah itu baru dilanjutkan dengan pembagian lahan (karang) dan penentuan jenis bangunan. Oleh karena itu, di bagian hulu pekarangan rumah tinggal tradisional Bali adalah sanggah (tempat suci), sedangkan bagian hilirnya adalah teba (tempat ternak).

\section{Hulu Kaja dan Bentuk Tata Letak Sanggah di Banjar Bedugul}

\subsection{Hulu Kaja di Banjar Bedugul}

Di Banjar Bedugul, hulu kaja-nya berbeda dengan Desa Penatahan sebagai desa induk. Jika arah kaja Desa Penatahan mengarah ke Gunung Batu Kau, maka arah kaja Banjar Bedugul mengarah ke Pura Batur Jati. Pura ini terletak di arah timur laut Banjar Bedugul. Dari perhitungan kompas, posisi Banjar Bedugul miring mengarah ke timur laut dan di arah hulu banjar terdapat Pura Batur Jati. Sedangkan hilir dari banjar mengarah ke jalan besar yang menghubungkan Desa Penatahan dan Gunung Batu Kau.

Dari penuturan tetua di Banjar Bedugul, representasi kolektif tentang hulu kaja terbentuk dari cerita yang tersurat dalam lontar di Pura Batur Jati. Menurut Jro Mangku I Ketut Karmina, saat Raja Tabanan ke-8 yang bergelar Sri Haji Murmakules datang ke Desa Asah (sekarang Desa Penatahan), penduduk desa menunjuk Pura Batur Jati sebagai arah kaja (Monografi, 2011). Berdasarkan cerita tersebut, warga Banjar Bedugul kemudian menerima hal tersebut sebagai representasi kolektif. Cerita tersebut dianggap fakta yang kuat karena menyangkut nilai-nilai kepercayaan, serta diulang terus menerus antar generasi.

Bagi warga Banjar Bedugul kondisi ini membentuk pola pikir yang mengkristal sebagai 
Arah Hulu Kaja Desa Penatahan ke Gunung Batu $\mathrm{Kau}$

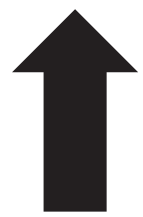

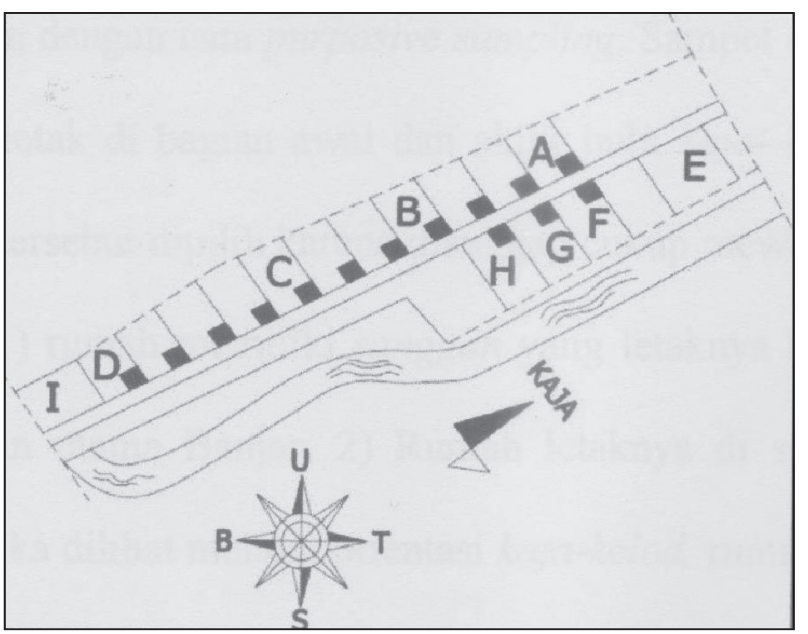

Gambar 2. Orientasi Hulu Kaja di Banjar Bedugul (Sumber : Dokumen Pribadi, 2020)

\section{Keterangan :}

A. Rumah Mangku I Ketut Karmina

B. Rumah I Nyoman Rajeng

C. Rumah I Wayan Ruka

D. Rumah I Gede Nur Cahya

E. Pura Batur Jati (hulu kaja)

F. Rumah I Nyoman Ridun

G. Rumah I Wayan Subagia

H. Rumah Ni Ketut Sugiti

I. Penyelipan padi representasi kolektif yang berulang. Hal inilah yang membuat warga Banjar Bedugul wajib mengikuti cerita tersebut, meskipun tidak ada aturan tertulis yang mengharuskan. Ketaatan ini berkaitan dengan komitmen moral bersama. Komitmen ini diikuti pula oleh dua pendatang dari desa lain, yakni keluarga Ni Ketut Sugiti dan I Gede Nur Cahya. Keduanya menuturkan bahwa mereka mengikuti pakem itu secara nurani semata. Kondisi ini tampak sebagai sebuah karakter wajib berdasarkan komitmen moral, yang terbentuk dalam suatu hubungan sosial masyarakat. Berikut (gambar 2.) yang menjelaskan fenomena di atas.

Dari gambar di atas, nampak perbedaan arah hulu kaja pada Desa Penatahan dan Banjar Bedugul. Nampak posisi Pura Batur Jati sebagai hulu desa yang ditunjukkan oleh huruf (E). Nampak juga layout pemukiman warga mengikuti arah orientasi hulu tersebut. Sedangkan hulu kaja Desa Penatahan mengarah ke Gunung Batu Kau. Dari hasil observasi, hulu ke Pura Batur Jati dapat dianggap sebagai hulu makro bagi pemukiman warga di Banjar Bedugul. Selain itu, dari hasil wawancara didapatkan hulu kedua yaitu menuju ke arah jalan umum. Dari hasil observasi, hulu ini lebih mengarah pada konteks mikro dalam rumah tinggal. Hulu ke jalan digunakan untuk menentukan pola penataan rumah tinggal dalam suatu pekarangan. Berikut gambar yang menjelaskan hal tersebut.

Jika orientasi hulu-teben dalam kosmologi masyarakat Bali didasarkan pada kontur alam dan matahari, maka orientasi hulu-teben di Banjar Bedugul berbeda. Orientasi hulu kawasan (makro) mengarah ke Pura Batur Jati. Dari segi kontur kawasan, Pura Batur Jati letaknya paling tinggi. Ini sangat mirip dengan orientasi hulu masyarakat Bali pada umumnya. Orientasi hulu masyarakat Bali menggunakan gunung karena memiliki letak tertinggi dari segi kontur wilayah. Menurut masyarakat Bali, gunung adalah tempat yang sakral. Gunung adalah tempat roh-roh suci dan arwah nenek moyang (Reuter, 2002). Berdasarkan hal ini, hulu ke gunung juga adalah cerminan sudut pandang religius masyarakat Bali.

Berdasarkan penjelasan di atas, arah hulu di Banjar Bedugul dan Bali pada umumnya sangat mirip. Kemiripan ini dilihat dari pemahaman orientasi hulu berdasarkan kondisi kontur tertinggi sebuah wilayah. Baik gunung ataupun Pura Batur Jati, sama-sama berada di kontur tertinggi. Selain itu, gunung dan Pura Batur Jati dipandang sebagai tempat yang sakral. Keduanya sangat mirip apabila dilihat dari sudut pandang religius masyarakat Bali.

Namun, hulu ke jalan berbeda dengan konsep hulu-teben masyarakat Bali pada umumnya. Hulu ke jalan di Banjar Bedugul, digunakan sebagai hulu dalam tata letak bangunan rumah tinggal masing-masing warga. Sanggah sebagai ruang sakral diletakkan paling hulu yang posisinya dekat jalan. Selanjutnya baru diikuti oleh area rumah tinggal dan teba. Dari hasil 


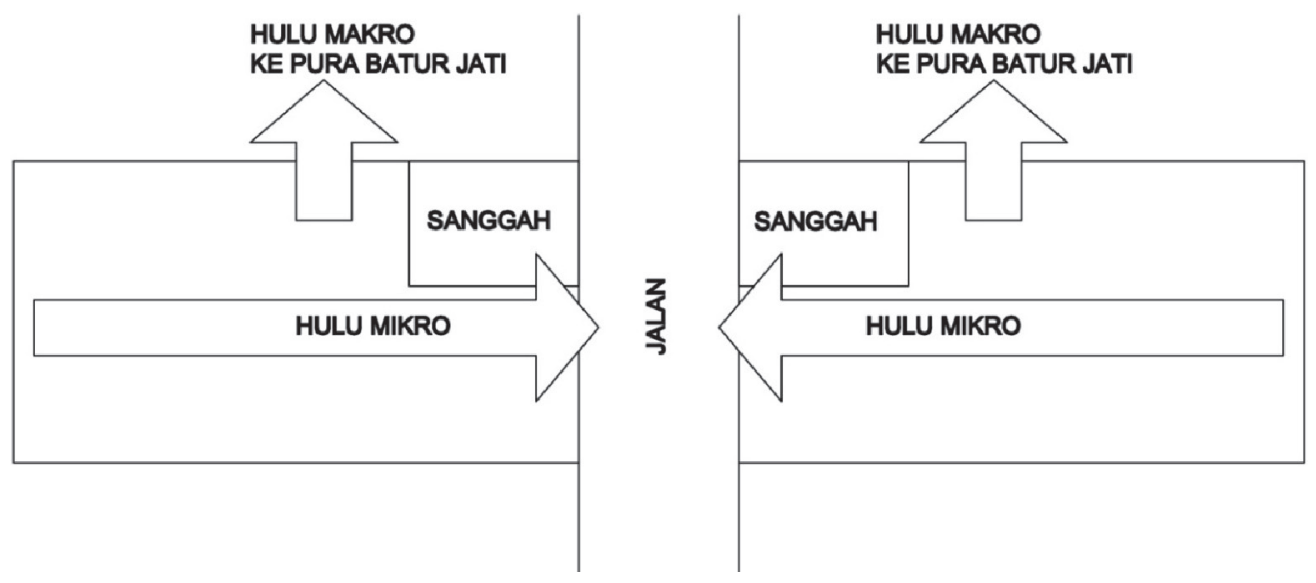

Gambar 3. Hulu Makro dan Mikro di Banjar Bedugul

(Sumber : Dokumen Pribadi, 2020)

wawancara, secara umum masyarakat Banjar Bedugul tidak mengetahui perihal hulu ke jalan ini. Mereka hanya mengatakan sudah mendapatkan demikian dari dulu. Dari penjelasan ini diperoleh satu pandangan, bahwa hulu ke jalan menjadi sebuah fenomena unik dalam arsitektur tradisional Bali. Selanjutnya diharapkan dapat dilakukan penelitian lebih dalam untuk menggali fenomena ini.

\subsection{Bentuk Tata Letak Sanggah pada Rumah Tinggal Warga di Banjar Bedugul}

Di Banjar Bedugul, sanggah diletakkan di depan pintu masuk pekarangan rumah tinggal. Adanya posisi jalan dengan orientasi kaja-kelod, menyebabkan peletakan sanggah ini nampak berada di kaja-kangin dan kaja-kauh dari posisi jalan. Berikut sampel layout rumah tinggal dan posisi sanggah di Banjar Bedugul.

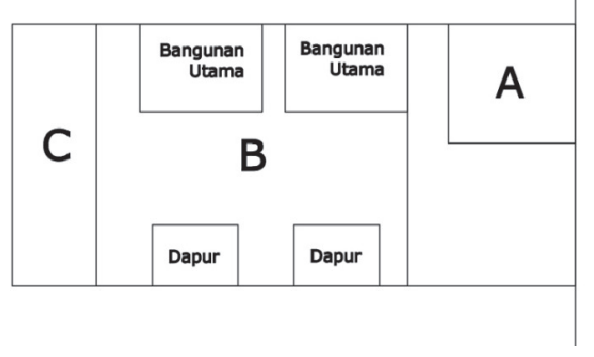

Jalan

Kaja

\section{Keterangan :}
A. Sanggah B. Pemukiman
C. Teba

Gambar 4. Layout Rumah Keluarga I Ketut Karmina (Sumber : Dokumen Pribadi, 2020)

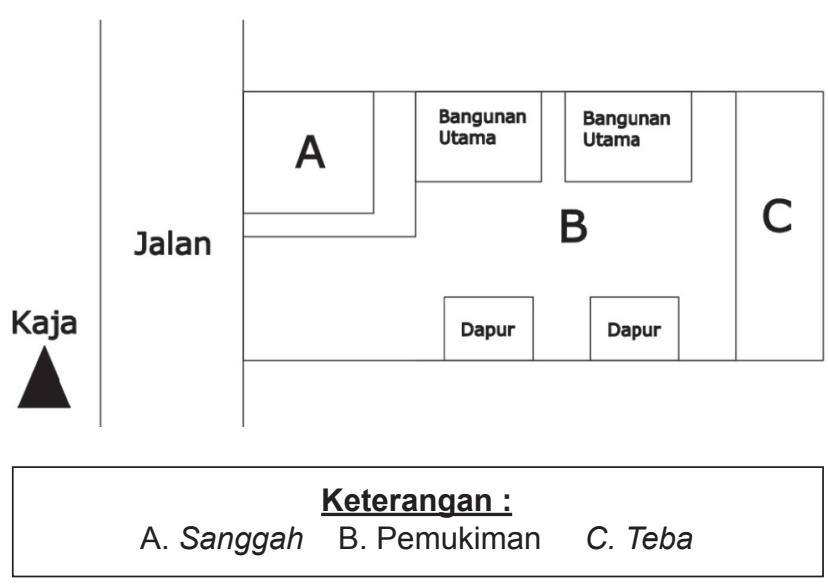

Gambar 5. Layout Rumah Keluarga I Nyoman Ridun (Sumber : Dokumen Pribadi, 2020)

Berdasarkan layout tersebut, sanggah terletak di pinggir jalan dekat pintu masuk pekarangan. Tata letak sanggah ini sama bagi seluruh warga di Banjar Bedugul. Selain itu, apabila diamati dengan seksama, nampak pola linear pada pekarangan rumah tinggal warga. Dari observasi yang dilakukan, seluruh rumah tinggal memiliki bentuk tata letak bangunan yang sama. Bangunan sanggah terletak di depan pekarangan, bangunan rumah utama diletakkan di bagian kaja area pekarangan, sedangkan bangunan dapur dan lumbung diletakkan di bagian kelod area pekarangan Dari hasil wawancara dengan Jro Mangku I Ketut Karmina, didapat penjelasan apabila terdapat kepala keluarga baru, tata letak ini akan berlanjut secara linear ke arah teba (paling ujung akhir pekarangan). 
Tata letak rumah tinggal warga mengikuti pola linear dan sanggah terletak di hulu perkarangan. Setelah sanggah kemudian terdapat tempat tinggal masing-masing kepala keluarga. Masing-masing kepala keluarga menempati satu area pekarangan. Pembagian pekarangan ini mengikuti pola linear. Pembagian pekarangan ini terus berlanjut hingga ke hilir pekarangan. Jika ada kepala keluarga baru, ia akan ditempatkan di hilir bangunan tempat tinggal lain.

Dari hasil wawancara, diperoleh keterangan bahwa hulu yang digunakan untuk penentuan tata letak sanggah di Banjar Bedugul ada dua, yaitu hulu ke jalan dan hulu ke Pura Batur Jati. Kedua orientasi hulu ini digunakan sebagai acuan dalam metakkan sanggah di areal pekarangan. Adanya orientasi ini menyebabkan pola tata letak sanggah berada di arah kajakangin dan kaja-kauh jika dilihat dari sumbu jalan banjar.

\section{Nilai-nilai dalam Tata Letak Sanggah di Banjar Bedugul}

Menurut Hendriyana (2009), artefak budaya fisik adalah budaya materi yang diciptakan oleh sekelompok masyarakat komunal secara kolektif. Kemudian kesepakatan komunal ini diperkuat melalui konvensi masyarakat budaya setempat. Artefak budaya fisik memiliki bentuk yang berasal dari transformasi data, fakta, situasi, dan kejadian alamiah. Kondisi ini kemudian membentuk nilai bagi manusia. Nilai yang muncul bersifat nampak (tangible) dan tersembunyi (intangible). Nilai-nilai ini tidak terpisahkan dari artefak budaya fisik.

Berdasarkan uraian di atas, pola tata letak sanggah termasuk dalam artefak budaya fisik khususnya dalam bidang seni arsitektur. Pola tata letak sanggah memiliki nilai-nilai yang muncul dari pengaruh fenomena budaya setempat. Dari pengumpulan data yang dilakukan, fenomena yang melatarbelakangi nilai-nilai dalam tata letak sanggah dibagi menjadi empat Keempat fenomena ini didasarkan pada pemikiran mistis religius, kolektif, pelestarian, dan identitas. Dari fenomena ini muncul nilai-nilai yang melatarbelakangi tata letak sanggah di Banjar Bedugul.

\section{a) Nilai Mistis Religius}

Berdasarkan wawancara dengan pemangku I Ketut Karmina dan beberapa warga Banjar Bedugul, didapat nilai tata letak sanggah yang berhubungan dengan penghormatan terhadap leluhur dan perlindungan dari leluhur. Masyarakat menganggap sanggah sebagai tempat leluhur atau nenek moyang. Letaknya di hulu dekat dengan jalan adalah sebuah penghormatan bagi leluhur. Karena dalam konsep hulu-teben, hulu adalah kepala, sedangkan teben adalah kaki. Leluhur yang sangat dimuliakan hendaknya diletakkan di kepala bukan di kaki. Dengan begitu leluhur tidak akan murka dan mencelakai keturunannya.

Selain itu, masyarakat percaya bahwa dengan meletakkan sanggah di dekat pintu masuk pekarangan, akan membentengi mereka dari pengaruh negatif tak kasat mata. Sanggah merupakan tempat pemujaan leluhur dan dianggap sebagai tempat para leluhur mengawasi keturunannya. Keberadaan arwah leluhur dipercaya akan memberikan keamanan bagi keturunannya. Karena itu sanggah diletakkan di depan pekarangan, dengan tujuan agar arwah leluhur dapat membentengi keturunannya dari energi tak kasat mata yang memasuki pekarangan.

Berdasarkan pendapat di atas, tata letak sanggah berhubungan dengan nilai mistis religius. Sanggah bukan hanya berfungsi religius sebagai tempat pemujaan leluhur. Akan tetapi, sanggah juga berfungsi sebagai benteng energi negatif tak kasat mata yang masuk ke pekarangan rumah.

Jika dilihat dengan seksama, kemunculan cara pandang di atas berhubungan dengan pola pikir magis mistis dalam sebuah kebudayaan. Van Peursen (1976: 82), percaya bahwa cara berpikir ini bermula dari cara berpikir yang magis dan mistis dalam suatu budaya. Cara berpikir magis percaya bahwa semua fenomena di alam memiliki kekuatan yang tak terlihat. Pada saat yang sama, cara berpikir yang mistis percaya bahwa kekuatan magis ini dapat digunakan dalam kehidupan manusia. Adanya konsep magis dan konsep mistik menjadikan pikiran manusia membentuk mitos. Kemudian, mitos ini melahirkan konsep yang seolah-olah menjadi fakta. Konsep ini terkait dengan 
keberadaan hidup manusia. Akhirnya, ada hubungan yang masuk akal antara keberadaan manusia dan kekuatan di sekitarnya.

\section{b) Nilai Kolektif}

Kondisi kolektif menurut Durkheim dalam Scott (2011: 51), adalah kondisi dimana manusia mengorganisasikan pengalaman yang mereka dapatkan menjadi konsep. Dalam konsep ini berisi kepercayaan, ide, nilai, simbol, dan ekspektasi. Konsep ini kemudian membentuk cara berpikir umum dan kekal dalam suatu masyarakat tertentu atau kelompok sosial.

Dalam kondisi kolektif, ada istilah keterwakilan kolektif dan representasi kolektif. Keterwakilan kolektif adalah konsep yang tersebar secara sosial. Melalui konsep ini orangorang dapat menjalankan antara dunia alamiah dengan orang-orang yang mereka jumpai. Representasi kolektif adalah suatu fenomena mental yang berhubungan dengan cara orangorang mengorganisasikan hidupnya (2011: 51). Dari penjelasan ini, keterwakilan kolektif membentuk sebuah komitmen moral di dalamnya. Sedangkan representasi kolektif berhubungan dengan karakter wajib, dalam hubungan yang terbangun antar individu dalam kelompok sosial.

Lembaga sosial dan sistem masyarakat dibangun dari representasi kolektif (2011: 53). Lembaga sosial dan sistem masyarakat ini menjadi solid karena seluruh individu terikat satu sama lain. Ikatan ini terbentuk dari representasi kolektif bersama. Apabila ada individu yang masuk, maka individu ini harus mengikuti komitmen moral dalam hubungan sosial kelompok yang dimasukinya.

Dari penjelasan di atas, fenomena yang sama terjadi pada tata letak sanggah di Banjar Bedugul. Dari penuturan warga Banjar Bedugul, didapat kondisi kolektif yang dijalankan sehubungan dengan tata letak sanggah. Kondisi kolektif ini diikuti tanpa aturan tertulis. Hanya bersifat turun-temurun dan penghargaan terhadap nenek moyang.

Peletakan sanggah di depan pintu masuk pekarangan adalah sebuah representasi kolektif. Dalam implementasinya tidak ada aturan tertulis. Namun, hanya didasarkan pada keterwakilan kolektif akan nilai kepercayaan, karakter wajib, dan komitmen moral. Menurut penuturan beberapa warga, sanggah dengan hulu ke jalan sudah mereka dapati secara turuntemurun. Kondisi ini tidak berani mereka ubah, karena sudah diwariskan. Selain itu, ini berhubungan dengan ikatan moral terhadap leluhur. Hal ini menunjukkan representasi kolektif yang mengakar dalam pikiran warga Banjar Bedugul. Mereka mengikuti nilai-nilai yang diwariskan leluhurnya sebagai sebuah karakter wajib.

\section{c) Nilai Pelestarian}

Berdasarkan wawancara, didapat nilai pelestarian arsitektur tradisional dari peletakan sanggah di Banjar Bedugul. Dari wawancara didapat beberapa pernyataan sehubungan dengan tata letak ini di masa depan. Pernyataan itu secara umum mengatakan, "sampun napetang sekadi niki, ten bani ngubah" , terjemahannya : "sudah mendapatkan seperti ini, tidak berani mengubah". Pernyataan ini menunjukkan adanya pelestarian yang terjadi. Pernyataan yang mengatakan tidak berani mengubah, mengindikasikan kondisi ini akan terus berlanjut di masa datang. Artinya di masa mendatang, posisi tata letak ini akan tetap ada.

Bentuk pelestarian ada dua cara yakni pelestarian preservatif dan pelestarian konservatif. Pelestarian preservatif dilakukan dengan cara meniru, menyimpan, dan merawat, sebagai bentuk dokumentasi. Sedangkan pelestarian konservatif dilakukan dengan cara mempertahankan dan mengembangkan nilai (Kartika, 2007: 63). Berdasarkan penjelasan ini, peletakan sanggah merupakan motivasi untuk menjaga warisan leluhur. Pelestariannya bukan hanya bentuk tata letak sanggah, tetapi juga nilai-nilai di dalamnya. Dengan demikian, pelestarian pola tata letak sanggah ini tergolong pelestarian konservatif.

Perilaku ini terkait dengan kebutuhan manusia akan keberadaannya. Berkat pelestarian ini, masyarakat Banjar Bedugul akan meninggalkan jejak sejarah yang dapat menjelaskan eksistensinta. Tentunya masyarakat Banjar Bedugul berharap agar warisan ini diterima oleh anak cucu mereka sebagai jejak eksistensi mereka. 


\section{d) Nilai Identitas}

Menurut Berger (2010: 125), identitas adalah tanda yang mengandung segala sesuatu untuk menyatakan sesuatu atau diri sendiri. Tanda ini mencakup nama, status, kepribadian, dan masa lalu. Identitas juga memiliki pembeda yang khas dan bersifat berkesinambungan. Berdasarkan pernyataan tersebut, dapat dikatakan bahwa kondisi yang berlangsung selama bertahuntahun dan tetap ada adalah sebuah identitas. Kondisi tersebut kemudian muncul sebagai tanda pernyataan diri yang berbeda dengan orang lain atau lingkungan sosialnya. Tanda ini, kemudian dapat dianggap sebagai pernyataan diri yang sah.

Di Banjar Bedugul, pola tata letak sanggahnya adalah sebuah identitas. Pola tata letaknya menjadi pembeda dengan pola tata letak sanggah lain di Bali. Daerah lain meletakkan sanggah-nya di arah kaja-kangin, sedangkan di Banjar Bedugul sanggah-nya diletakkan di depan pintu masuk pekarangan. Sehubungan dengan identitas, kondisi ini muncul sebagai pernyataan diri. Ini dilatarbelakangi oleh masa lalu dan kepercayaan terhadap warisan leluhur. Bentuk tata letak sanggah tersebut, telah dilaksanakan selama berpuluh tahun dan menetap dalam nalar warga Banjar Bedugul sebagai sebuah identitas.

\section{SIMPULAN}

Tata letak sanggah di Banjar Bedugul berada di depan pintu masuk pekarangan. Kondisi ini muncul dari representasi warga untuk meletakkan sanggah dengan hulu ke jalan dan Pura Batur Jati. Penentuan orientasi ini, menyebabkan sanggah berada di arah kajakangin dan kaja-kauh, bila dilihat dari hulu jalan umum di Banjar Bedugul. Nilai yang didapat dari wawancara dan observasi adalah nilai-nilai yang didasarkan pada pemikiran mistis religius, kolektif, pelestarian dan identitas. Nilai mistis religius berisi kepercayaan bahwa dengan meletakkan sanggah di dekat pintu masuk pekarangan, akan membentengi mereka dari pengaruh negatif tak kasat mata. Nilai kolektif muncul dari keterwakilan kolektif akan nilai kepercayaan, karakter wajib, dan komitmen moral. Seluruh kondisi ini didasarkan pada warisan nilai-nilai dari leluhur. Nilai pelestarian mengacu pada ketaatan moral, terhadap perlindungan nilai dan bentuk tata letak sanggah. Atas dasar ini, pelestariannya bersifat konservatif. Nilai identitas muncul sebagai pernyataan diri yang membedakan pola tata letak sanggah di Banjar Bedugul dan di Bali pada umumnya.

\section{DAFTAR PUSTAKA}

Berger, A. A. 2010. Pengantar Semiotika: Tanda-tanda dalam Kebudayaan Kontemporer. Yogyakarta: Tiara Wacana.

Dwijendra, N. K. A. 2003. Perumahan dan permukiman tradisional Bali. Jurnal Permukiman "Natah, $1(1), 8-24$.

2010. Arsitektur Bangunan Suci Hindu Berdasarkan Asta Kosala-Kosali. Denpasar: Udayana University Press.

Gelebet, I. N. 1986. Arsitektur Tradisional Daerah Bali. Denpasar: Departemen Pendidikan dan Kebudayaan Provinsi Bali.

Gumilang, G. S. 2016. Metode penelitian kualitatif dalam bidang bimbingan dan konseling. Jurnal Fokus Konseling, 2(2).

Hendriyana, H. 2009. Metodologi kajian artefak budaya fisik: fenomena visual bidang seni. Sunan Ambu Press, STSI Bandung.

Kartika, D. S. 2007. Estetika Seni Rupa Nusantara. Solo: ISI Press Surakarta. 
Monografi. 2011. Monografi Desa Penatahan. Tabanan: Desa Penatahan

Reuter, T. A. 2002. Custodians of the sacred mountains: Culture and society in the highlands of Bali. University of Hawaii Press.

Scott, J. 2011. Sociology: The Key Concept. Jakarta: Rajawali Press.

Soebandi, K. 2008. Riwayat Merajan di Bali. Denpasar: CV. Kayumas Agung.

Suardana, I. N. G., Aryawan, I. W., \& Widiyani, D. M. S. 2018. Nilai Filosofis dan Tata Cara Pembangunan "Pelinggih Gedong Saren". Jurnal Anala, 6(1), 53-72.

Suarya, I. M. 2003. Peranan natah di dalam kehidupan masyarakat bali. Jurnal Permukiman "Natah, $1(1)$.

Sudana, O., Suryadana, A., \& Bayupati, A. 2020. Rancang Bangun Sistem Informasi Rumah Tradisional Bali Berdasarkan Asta Kosala-Kosali Berbasis Web. Jurnal Teknologi Informasi dan Ilmu Komputer, 7(5), 1001-1010.

Sugiyono, S. 2010. Metode Penelitian Kuantitatif dan Kualitatif dan R\&D. Bandung: ALFABETA.

Suryada, I. G. A. B. 2012. Konsepsi Tri Mandala dan Sangamandala dalam Tatanan Arsitektur Tradisional Bali. Sulapa, 4(1), 23-32.

Van Peursen, C. A. 1976. Strategi kebudayaan. Penerbitan Kanisius.

Widiyani, D. M. S., \& Wiriantari, F. 2019. Karakteristik Bangunan "Bale Meten" Serta Proses Pembangunannya. Undagi : Jurnal Ilmiah Jurusan Arsitektur Universitas Warmadewa, 7(1), 29-35.

Wikarman, I., \& Singgih, N. 1993. Ngodalin Pada Sanggah Pemrajan. Bangli: Yayasan Widya Shanti. Wikarman, I. N. S. 1998. Leluhur Orang Bali. Bangli: Yayasan Widya Shanti.

Winanti, N. P. 2009. Pura Keluarga Dan Pratima. Pustaka Bali Post.

Yulianasari, A. A. A. S. R., Wiriantari, F., Widiyani, D. M. S., \& Wijaatmaja, A. B. M. 2020. Tipologi dan Konsep Tata Letak Sanggah pada Karang Umah di Desa Adat Bayung Gede. Jurnal Arsitektur ZONASI, 3(3), 261-269. 